\title{
Secretory component production by human bronchial epithelial cells is upregulated by interferon gamma
}

\author{
V. Godding*+, Y. Sibille*+, P.P. Massion*+, M. Delos*, C. Sibille\#, P. Thurion*+, D. Giffroy+, \\ A. Langendries ${ }^{+}$, J.P. Vaerman+
}

Secretory component production by human bronchial epithelial cells is upregulated by interferon gamma. V. Godding, Y. Sibille, P.P. Massion, M. Delos, C. Sibille, P. Thurion, D. Giffroy, A. Langendries, J.P. Vaerman. CERS Journals Ltd 1998.

ABSTRACT: Secretory immunoglobulin A (S-IgA) participates in the first noninflammatory line of defence of the respiratory tract. S-IgA consists of dimeric IgA (dIgA) produced by plasma cells and secretory component (SC) produced by epithelial cells.

This study compared SC production by primary cultures of human bronchial epithelial cells (HBEC) and by respiratory epithelial cell lines.

Among the cell lines, A549 did not produce detectable SC, 16HBE produced very low levels of SC, while CALU-3 produced significant levels of SC. HBEC produced SC in nonpolarized and polarized primary cultures, where it was secreted apically. Polarized HBEC transcytosed radiolabelled and cold $\mathrm{dIgA}$, resulting in the presence of S-IgA in their apical media. SC production and IgA transcytosis by polarized HBEC were upregulated by interferon- $\gamma($ IFN- $\gamma)$ after $48 \mathrm{~h}$. By reverse transcriptionpolymerase chain reaction, no SC messenger ribonucleic acid (mRNA) was detected in A549 and 16HBE, while SC mRNA in CALU-3 was comparable to that of HBEC incubated for $48 \mathrm{~h}$ with IFN- $\gamma$. By immunocytochemistry, HBEC expressed SC immunostaining and its intensity increased after $48 \mathrm{~h}$ with IFN- $\gamma$.

It is concluded that human bronchial epithelial cells produce secretory component and transcytose dimeric immunoglobulin $\mathrm{A}$ in vitro. These processes were apically polarized and upregulated by interferon- $\gamma$. Among the cell lines studied, only CALU3 expressed secretory component-messenger ribonucleic acid and produced detectable secretory component.

Eur Respir J 1998; 11: 1043-1052.
*UCL Mont-Godinne, Yvoir, Belgium. +Experimental Medicine Unit, ICP, UCL, Brussels, Belgium. \#Genetics Center of Loverval, Loverval, Belgium.

Correspondence: V. Godding

Experimental Medicine Unit, ICP

74, Av. Hippocrate

B-1200 Brussels

Belgium

Fax: 3227647430

Keywords: Bronchial epithelium immunoglobulin A transcytosis interferon gamma primary culture

secretory component

Received: March 261997

Accepted after revision February 161998

This study was supported in part by a grant from the Fondation Mont-Godinne, and by grant ARC 94/99-172 from the Direction Générale de la Recherche Scientifique de la Communauté Française de Belgique.
The respiratory tract in humans represents a large mucosal area exposed to the environment. The secretory immune system is the first, noninflammatory line of defence, protecting the respiratory tract from viral and bacterial infections. Secretory immunoglobulin $\mathrm{A}(\mathrm{S}-\operatorname{Ig} \mathrm{A})$ is the major immunoglobulin present in human airway secretions [1]. The humoral secretory immune response depends on interactions between the B-cell system for the production of J-chain-containing polymeric $\operatorname{IgA}(\mathrm{pIgA})$ and the mucosal epithelium for the epithelial expression of secretory component (SC), respectively. SC is the soluble extracellular domain of the polymeric Ig receptor (pIgR) present on the basolateral surface of most epithelial cells. The pIgA antibodies produced by plasma cells are transported into mucosal secretions by transcytosis through epithelial cells $[2,3]$. The pIgR at the basolateral pole of the epithelium, with or without bound $\mathrm{pIgA}$, is constitutively endocytosed and transported by vesicles to the apical pole, where pIgR vesicles fuse with the apical membrane. A proteolytic cleavage then occurs between the extracellular and membrane domains of the pIgR, resulting in the release of SC or S-IgA, a complex of mostly dimeric IgA $(\operatorname{dIgA}), \mathrm{J}$-chain and SC $[4,5]$. Immunohistology and immunofluorescence studies have demonstrated the presence of SC in bronchial epithelial cells and of IgA-containing plasma cells in the bronchial mucosa [6]. Moreover, pIgA and SC transcytosis have also been demonstrated by immunoelectron microscopy of bronchial mucosa [7]. In human pathology, decreased SC levels have been described in the bronchoalveolar lavage (BAL) fluid of asthmatic patients compared with normal controls [8]. Furthermore, a prospective study in children suggested a relationship between transient salivary IgA deficiency during the first year of life and the later development of bronchial hyperreactivity [9].

The production of SC by cultured human tracheal epithelial cells has been demonstrated to be influenced by cell polarization [10]. The influence of cell polarization on SC production was further stressed by studies using neoplastic colonic cells, demonstrating an enhancing effect of polarization on their in vitro SC production [11]. Cytokines such as interferon (IFN)- $\gamma[12,13]$, interleukin (IL)-4 [13, 14], tumour necrosis factor- $\alpha$ (TNF- $\alpha)$ [15], transforming growth factor- $\beta$ (TGF- $\beta$ ) [16], and IL- $1 \alpha$ and IL-1 [17] have been shown to increase SC production by intestinal epithelial cell lines.

The aim of this study was to investigate SC production by human bronchial epithelial cells in primary culture. 
The SC production by human bronchial epithelial cells (HBEC) was first evaluated and their SC production was compared with that of respiratory epithelial cell lines. The influence of cell polarization and IFN- $\gamma$ on SC production by confluent HBEC was further investigated at the protein and the mRNA level. Finally, the constitutive pIgA transcytosis by HBEC in the presence or absence of IFN- $\gamma$ was evaluated.

\section{Materials and methods}

\section{Reagents}

Rosswell Park Memorial Institute-1640 (RPMI) medium, transferrin, epidermal growth factor, insulin, retinol acetate, fibronectin, bovine serum albumin (BSA), pronase E, streptavidin peroxidase, extravidin alkaline phosphatase, biotin amidocaproate n-hydroxysuccinimide ester, paranitrophenylphosphate, chloroform, isopropanol, formaldehyde $37 \%$, diethylpyrocarbonate,3-(N-morpholino)propanesulfonic acid and salmon sperm deoxyribonucleic acid (DNA) were obtained from Sigma (St Louis, MO, USA). Eagle's minimal essential medium (MEM), Hanks' balanced salt solution with calcium and magnesium (HBSS), penicillin-streptomycin-amphotericin B solution, gentamycin, foetal calf serum (FCS), L-glutamine, trypsin ethylenediamine tetraacetic acid (EDTA), hydroxy-ethyl piperazine ethane sulfonate (HEPES), Hind III restriction enzyme, monophasic solution of phenol and guanidine isothiocyanate (TRIzol reagent) and agarose for RNA electrophoresis were purchased from Gibco BRL (Grand Island, NY, USA). Acetone, glycerol and $o$-phenylenediamine dihydrochloride (OPD) were purchased from Merck (München, Germany). Collagen (vitrogen) was purchased from Celtrix (Palo Alto, CA, USA). ${ }^{125}$ I, ${ }^{32} \mathrm{P}$ and radiolabelled nucleotides were obtained from Amersham (Little Chalfont, UK). The random primed DNA labelling kit was obtained from Boehringer Mannheim (Germany).

\section{Cytokines and antibodies}

Recombinant human IFN- $\gamma$ was obtained from Innogenetics (Antwerp, Belgium). Goat antihuman free SC antiserum and its affinity-purified antibodies were previously produced in the laboratory [18]. Biotinylated affinity-purified rabbit antigoat $\operatorname{IgG}(\mathrm{H}+\mathrm{L})$ antibodies were purchased from Sigma. Affinity-purified goat antihuman SC antibodies from the authors' laboratory were biotinylated by a standard procedure [19]. Rabbit antihuman IgA antibodies were prepared by affinity purification.

Monomeric, dimeric and polymeric human $\operatorname{IgA}$ were purified from the serum of a myeloma patient, as described previously [20]. Human free SC was affinity-purified from human milk by a method similar to that used to purify rat free SC from rat milk or bile [21].

\section{Respiratory epithelial cell culture}

HBEC: study subjects. Tumour-free segments of human bronchial tubes were removed from surgical specimens obtained from patients with resectable lung cancer. Cells derived from 28 patients were studied, including 23 male donors aged 66.2 \pm 10 yrs (mean \pm SD) and five female donors aged 58.6 \pm 6.6 yrs. None of these patients had received radiotherapy or chemotherapy prior to surgery. The protocol was approved by the Ethics Committee of the Cliniques Universitaires de Mont-Godinne. Each separate experiment was conducted with the cells isolated from one donor.

HBEC: isolation and culture in 96-well plates. Tumourfree segments of bronchial tubes were immediately removed from the surgical specimen and placed in cold RPMI containing $200 \mathrm{U} \cdot \mathrm{mL}^{-1}$ penicillin, $200 \mu \mathrm{g} \cdot \mathrm{mL}^{-1}$ streptomycin, $2.5 \mu \mathrm{g} \cdot \mathrm{mL}^{-1}$ amphotericin $\mathrm{B}, 50 \mu \mathrm{g} \cdot \mathrm{mL}^{-1}$ gentamycin and $2 \mathrm{mM}$ HEPES. The specimens were kept at $4^{\circ} \mathrm{C}$ and transferred to the cell-culture laboratory within $24 \mathrm{~h}$. The bronchial fragments were then carefully dissected from the lung parenchyma and rinsed with HBSS containing $200 \mathrm{U} \cdot \mathrm{mL}^{-1}$ penicillin, $0.2 \mathrm{mg} \cdot \mathrm{mL}^{-1}$ streptomycin, $2.5 \mu \mathrm{g} \cdot \mathrm{mL}^{-1}$ amphotericin $\mathrm{B}, 50 \mu \mathrm{g} \cdot \mathrm{mL}^{-1}$ gentamycin and $2 \mathrm{mM}$ HEPES at room temperature. After overnight enzymatic digestion at $4^{\circ} \mathrm{C}$ in RPMI with HEPES and antibiotics containing $0.05 \%$ pronase E, HBEC were detached by vigorous shaking, washed by centrifugation at $123 \mathrm{~g}$ for $10 \mathrm{~min}$ at room temperature, once in $10 \%$ FCS to stop the enzymatic digestion and then twice in the same medium without FCS. HBEC were then counted (Coulter counter, Harpenden, UK). HBEC were resuspended in RPMI containing $1 \mu \mathrm{g} \cdot \mathrm{mL}^{-1}$ insulin, $1 \mu \mathrm{g} \cdot \mathrm{mL}^{-1}$ transferrin, $10 \mathrm{ng} \cdot \mathrm{mL}^{-1}$ vitamin $\mathrm{A}, 10 \mathrm{ng} \cdot \mathrm{mL}^{-1}$ epidermal growth factor, $2 \mathrm{mM}$ L-glutamine, $200 \mathrm{U} \cdot \mathrm{mL}^{-1}$ penicillin, $0.2 \mathrm{mg} \cdot \mathrm{mL}^{-1}$ streptomycin, $2.5 \mu \mathrm{g} \cdot \mathrm{mL}^{-1}$ amphotericin B and $50 \mu \mathrm{g} \cdot \mathrm{mL}^{-1}$ gentamycin [22], hereafter referred to as defined medium. Cell density was adjusted to $1 \times 10^{6}$ cells $\cdot \mathrm{mL}^{-1}$. HBEC were seeded at $1 \times 10^{5}$ cells per well into 96 -well sterile tissue culture plates (Falcon; Becton-Dickinson, Franklin Lakes, NJ, USA) precoated for $2 \mathrm{~h}$ at room temperature with RPMI with antibiotics containing $2.9 \mu \mathrm{g} \cdot \mathrm{mL}^{-1}$ vitrogen, 10 $\mu \mathrm{g} \cdot \mathrm{mL}^{-1}$ fibronectin and $100 \mu \mathrm{g} \cdot \mathrm{mL}^{-1} \mathrm{BSA}$ (coating solution). The cell cultures were incubated at $37^{\circ} \mathrm{C}$ in humidified atmosphere with $5 \% \mathrm{CO}_{2}$. Nonadherent cells were removed by gentle washing with defined medium after 24 $\mathrm{h}$. Confluence was determined by daily inverted microscopic examination. In eight distinct experiments, HBEC from eight different donors were cultured to confluence. HBEC were then further cultured for $72 \mathrm{~h}$ with either control defined medium or defined medium containing 100 $\mathrm{U} \cdot \mathrm{mL}^{-1} \mathrm{IFN}-\gamma$. Media were collected and replaced every 24 $\mathrm{h}$ and stored at $-20^{\circ} \mathrm{C}$. HBEC were detached at $72 \mathrm{~h}$ after confluence with trypsin-EDTA and cell number and viability were again determined. Results, adjusted to $10^{5}$ cells as determined at $72 \mathrm{~h}$, are expressed as SC concentrations in $\mathrm{ng} \cdot \mathrm{mL}^{-1}$.

HBEC: culture on permeable filter inserts. HBEC isolated as above were seeded at a density of $1-2 \times 10^{6}$ cells $\cdot \mathrm{mL}^{-1}$ on transparent insert-type filters $(0.4 \mu \mathrm{m})$ for 24 -well tissue culture plates (Falcon) coated with the same coating solution. The volume of media used was $500 \mu \mathrm{L}$ in both upper and lower compartments. The double compartment filter insert system was used to allow epithelial cell polarization [23]. In this system, once the HBEC monolayer is 
confluent, the apical and basal compartments no longer directly communicate via the filter pores, allowing selective access to secretion products at the apical and basolateral poles of the cell monolayer. Cell confluence was determined by both microscopic examination and measurement of the transepithelial electrical resistance using a specific device (Millicell ERS, Millipore, Bedford, MA, USA). Four experiments on permeable filters were conducted under the conditions described, using HBEC from four different donors. Confluence was reached after $5 \pm 1$ days, as determined by microscopic examination and an electrical resistance of the HBEC monolayer $>600 \Omega \cdot \mathrm{cm}^{2}$. HBEC were then further cultured for $72 \mathrm{~h}$ with either control defined medium in both compartments, or defined medium containing $100 \mathrm{U} \cdot \mathrm{mL}^{-1} \mathrm{IFN}-\gamma$ in their apical compartment, and defined medium in the basolateral compartment. Basal and apical media were collected separately and replaced every $24 \mathrm{~h}$. HBEC were detached at $72 \mathrm{~h}$ after confluence with trypsin-EDTA and cell number and viability were again determined. Results are expressed as $\mathrm{SC}$ concentrations in $\mathrm{ng} \cdot \mathrm{mL}^{-1}$ and adjusted to $10^{5}$ cells as determined at $72 \mathrm{~h}$ after confluence.

\section{Cell culture for immunocytochemistry}

HBEC were seeded at $1 \times 10^{6}$ cells $\cdot \mathrm{mL}^{-1}$ on sterile 8 chamber glass slides (Lab-Tek, Nunc, Naperville, IL, USA) coated with the same coating solution. Confluence was reached after $72 \mathrm{~h}$. HBEC were incubated for $48 \mathrm{~h}$ in defined medium with or without (control) $100 \mathrm{U} \cdot \mathrm{mL}^{-1}$ IFN- $\gamma$. The media were then collected and the disposable plastic wells removed. The cells was fixed in acetone at $4^{\circ} \mathrm{C}$.

\section{Cultures of human respiratory epithelial cell lines}

Various human respiratory epithelial cell lines were selected to investigate their production of SC. A549, an im-mortalized alveolar type 2 epithelial cell line and CALU-3, an immortalized adenocarcinoma epithelial cell line derived from human lung adenocarcinoma, were purchas-ed from American Type Culture Collection (ATCC, Rock-ville, MD, USA). 16HBE, a bronchial epithelial cell line, was a generous gift from D. Gruenert. A549 and $16 \mathrm{HBE}$ cell lines were cultured in $150 \mathrm{~cm}^{2}$ flasks in MEM containing $10 \%$ FCS, $2 \mathrm{mM}$ L-glutamine, $100 \mathrm{U} \cdot \mathrm{mL}^{-1}$ penicillin, $0.1 \mathrm{mg} \cdot \mathrm{mL}^{-1}$ streptomycin and $2.5 \mu \mathrm{g} \cdot \mathrm{mL}^{-1}$ amphotericin B. The CALU-3 cell-line was cultured in MEM containing $10 \% \mathrm{FCS}, 100 \mathrm{U} \cdot \mathrm{mL}^{-1}$ penicillin, $0.1 \mathrm{mg} \cdot \mathrm{mL}^{-1}$ streptomycin, $2.5 \mu \mathrm{g} \cdot \mathrm{mL}^{-1}$ amphotericin $\mathrm{B}$ and $1 \%$ sodium pyruvate. The tissue culture flasks were coated with coating solution for all cell lines but A549. Media were collected every $24 \mathrm{~h}$ for $96 \mathrm{~h}$ after confluence and stored at $20^{\circ} \mathrm{C}$. At $96 \mathrm{~h}$ the cells were detached with trypsin-EDTA and cell counts determined as above.

\section{ELISA for SC and S-IgA}

Free SC was measured in culture media using an enzyme-linked immunosorbent assay (ELISA). In brief, 96-well plates were coated overnight with goat anti-human free SC affinity purified antibody $\left(1 \mu \mathrm{g} \cdot \mathrm{mL}^{-1}\right)$ and washed with phosphate-buffered saline (PBS)-Tween $0.1 \%$. An overcoating was then added for 45 min using PBS-4\% milk (Fat free powdered milk, Carnation; Nestlé, Vevey, Switzerland). After three washings with PBS-Tween, 100 $\mu \mathrm{L}$ cell media was added to the wells for $2 \mathrm{~h}$ incubation at $37^{\circ} \mathrm{C}$. After further washings, the same biotinylated goat antihuman $\mathrm{SC}$ IgG was added for $2 \mathrm{~h}$ at $37^{\circ} \mathrm{C}$, as a secondary antibody. The wells were then washed three times using $0.01 \mathrm{M}$ Tris- $\mathrm{HCl}$, pH 7.5, with $130 \mathrm{mM} \mathrm{NaCl}$ and $0.1 \%$ Tween. Then, $100 \mu \mathrm{L}$ extravidine-conjugated alkaline phosphatase $(1: 20,000$ in the same buffer) was added for $30 \mathrm{~min}$ at $37^{\circ} \mathrm{C}$. After five washings with the same buffer, $100 \mu \mathrm{L}$ of paranitrophenylphosphate $\left(1 \mathrm{mg} \cdot \mathrm{mL}^{-1}\right.$ in $10 \%$ diethanolamine, $\mathrm{pH} 9.8$, with $0.5 \mathrm{mM} \mathrm{MgCl}_{2}$ and $0.2 \% \mathrm{NaN}_{3}$ ) was added as the substrate. After $40 \mathrm{~min}$ at $37^{\circ} \mathrm{C}$, the reaction was stopped by adding $100 \mu \mathrm{L} \cdot$ well $^{-1}$ $3 \mathrm{M} \mathrm{NaOH}$. The plates were read at $492 \mathrm{~nm}$ on a Titertek Multiscan Plus MKII (Flow Labs, Brussels, Belgium). Each sample was measured in duplicate and differences between duplicates never reached $10 \%$. Duplicate standard curves using known concentrations of purified human free SC (from $0.4-50 \mathrm{ng} \cdot \mathrm{mL}^{-1}$ ) were included on each plate. The sensitivity of the method was $0.5 \mathrm{ng} \cdot \mathrm{mL}^{-1}$.

For S-IgA, 96-well plates were coated with rabbit antihuman $\operatorname{IgA}$ antibody $\left(1 \mu \mathrm{g} \cdot \mathrm{mL}^{-1}\right)$ and washed with PBSTween. After overcoating at $37^{\circ} \mathrm{C}$ for 45 min with PBS-4\% milk (three washes), $100 \mu \mathrm{L}$ cell media were added to the wells for $2 \mathrm{~h}$ incubation at $37^{\circ} \mathrm{C}$. After further washings, the biotinylated affinity-purified goat antihuman SC antibody was then added for $2 \mathrm{~h}$ at $37^{\circ} \mathrm{C}$, as a secondary antibody at $0.5 \mu \mathrm{g} \cdot \mathrm{mL}^{-1}$. The assay was then performed as described for SC. Duplicate standard curves consisted of several dilutions of dimeric S-IgA isolated from human milk (from 0.8-100 ng. $\mathrm{mL}^{-1}$ ) [18].

\section{Immunocytochemistry}

Indirect immunostaining of acetone-fixed HBEC was performed using goat antihuman SC antiserum (1:500) for overnight incubation at $4{ }^{\circ} \mathrm{C}$. Control cells included staining with $1 \%$ BSA in $0.01 \mathrm{M}$ Tris- $\mathrm{HCl}$ buffered saline, $\mathrm{pH}$ 7.4. The secondary antibody, a biotinylated rabbit antigoat $\mathrm{IgG}$, was used at 1:500 for $30 \mathrm{~min}$ at room temperature. After washing once with Tris-buffered saline, the reaction was amplified with streptavidin-peroxidase conjugate (1: 500 ) for $30 \mathrm{~min}$ at room temperature. After further washings, the reaction was revealed by adding $0.6 \mathrm{mg} \cdot \mathrm{mL}^{-1}$ diaminobenzidine in Tris $\left(9.7 \mathrm{mg} \cdot \mathrm{mL}^{-1}\right)$ and Trizma® $-\mathrm{HCl}$ $\left(6.69 \mathrm{mg} \cdot \mathrm{mL}^{-1}\right)$ containing $10 \mu \mathrm{L} \cdot \mathrm{mL}^{-1}$ concentrated pure $\mathrm{H}_{2} \mathrm{O}_{2}$ for $10 \mathrm{~min}$ at room temperature.

In three experiments, mouse $\mathrm{IgG} 2 \mathrm{a}$ monoclonal antibody anticytokeratins 8 and 18 (reaching both cytokeratins by the same epitope) (clone CAM 5.2, Becton Dickinson) was used to establish the epithelial nature of the HBEC. The antibody was used at a 1:10 dilution for an overnight incubation at $4^{\circ} \mathrm{C}$. The secondary antibody was biotinylated rabbit anti-mouse IgG (Prosan, Ghent, Belgium). The reaction was amplified and revealed as described above. An irrelevant mouse IgG2a (Prosan) monoclonal antibody was used as the isotype control. 


\section{Transcytosis experiments using labelled and cold pIgA}

Transcytosis experiments used $125 \mathrm{I}$-radiolabelled dIgA. In brief, $100 \mu \mathrm{L} \mathrm{dIgA}\left(1 \mathrm{mg} \cdot \mathrm{mL}^{-1}\right.$ in $0.15 \mathrm{M}$ Na phosphate buffer, $\mathrm{pH}$ 7.4) was added to $0.5 \mathrm{mCi} \mathrm{Na-125I}$ (carrier and reducing agent free; Amersham) diluted in $100 \mu \mathrm{L}$ of the same buffer. Then, $40 \mu \mathrm{L}$ fresh chloramine $\mathrm{T}\left(1 \mathrm{mg} \cdot \mathrm{mL}^{-1}\right.$ in water) was admixed by stirring for $15 \mathrm{~s}$ at room temperature. The labelling reaction was stopped by the addition of $100 \mu \mathrm{L}$ fresh sodium metabisulfite $\left(1 \mathrm{mg} \cdot \mathrm{mL}^{-1}\right)$. The radiolabelled protein was then separated from free iodide by passage on a $0.8 \times 5 \mathrm{~cm}$ column of Dowex ${ }^{\circledR}-A G 1 \mathrm{X} 8$ (200-400 mesh; BioRad, Richmond, CA, USA) equilibrated with $0.5 \%$ BSA in PBS. The column was then eluted with the same buffer and the ${ }^{125 I-d I g A}$ was collected in a total of $3 \mathrm{~mL}$ PBS-BSA. In all experiments the percentage of $10 \%$ trichloroacetic acid (TCA)-precipitable radiolabelled $\operatorname{Ig}$ A was higher than $95 \%$. Specific activity ranged from $303,000-4,929,000$ counts per minute $(\mathrm{cpm}) \cdot \mu_{\mathrm{g}}{ }^{-1}$ 125I-dIgA.

For transcytosis experiments, HBEC were grown to confluence on coated 24-well inserts as described previously. After confluence, ${ }^{125} \mathrm{I}-\mathrm{dIgA}$ at a concentration of 8 $\mu \mathrm{g} \cdot \mathrm{mL}^{-1}$ was added to the basolateral compartment of the HBEC monolayer. A control insert, included in all experiments, received the same concentration of radiolabelled dimeric IgA together with $4.2 \mathrm{mg} \cdot \mathrm{mL}^{-1}$ cold $\mathrm{pIgA}$ from the same myeloma (mostly dimers $(>70 \%)$ and higher polymers, but $<5 \%$ monomers). Apical media were collected and replaced every $24 \mathrm{~h}$ for 3 days, and TCA-precipitable counts measured in an automatic gamma counting system MR480 (Kontron). Cumulative results are expressed as ng 125I-dIgA $\cdot \mathrm{mL}^{-1}$.

\section{Isolation of $m R N A$ from HBEC and cell lines}

HBEC isolated as described above were grown to confluence on one sterile tissue culture Petri dish (surface area $58 \mathrm{~cm}^{2}$; Greiner, Frickenhausen, Germany) coated with coating solution. Confluence was reached after 4 days. HBEC were then further cultured in defined medium with $100 \mathrm{U} \cdot \mathrm{mL}^{-1} \mathrm{IFN}-\gamma$ for $48 \mathrm{~h}$. The media were collected and the cells were incubated at room temperature for $5 \mathrm{~min}$ with $5 \mathrm{~mL} \cdot$ dish $^{-1}$ of TRIzol reagent according to the manufacturers' instructions. Then $1 \mathrm{~mL}$ chloroform was admixed to the cell-TRIzol preparation for $3 \mathrm{~min}$ at room temperature. The preparation was collected and centrifuged at $12,000 \mathrm{~g}$ for $15 \mathrm{~min}$ at $4^{\circ} \mathrm{C}$. The RNA-containing supernatant was carefully collected; RNA was precipitated by addition of isopropanol (50\% of the initial TRIzol volume). After 10 min of incubation at room temperature, the RNA precipitate was centrifuged at $12,000 \mathrm{~g}$ for $10 \mathrm{~min}$ at $4^{\circ} \mathrm{C}$. After discarding the supernatant, the RNA pellet was washed twice with $70 \%$ ethanol in sterile water, dried and redissolved in sterile water.

\section{Reverse transcription}

Reverse transcription was performed according to the method described by FinKBEINER et al. [24], but using $10 \mu \mathrm{g}$ total RNA from each extract instead of $1-2 \mu \mathrm{g}$.

\section{Polymerase chain reaction}

For each polymerase chain reaction (PCR) mixture, 3 $\mu \mathrm{L}$ of the reverse transcription (RT) products preheated at $95^{\circ} \mathrm{C}$ for 3 min were mixed to $0.25 \mu \mathrm{L}$ Taq DNA polymerase $\left(5 \mathrm{U} \cdot \mathrm{mL}^{-1}\right), 1 \mu \mathrm{L}$ dNTP $(10 \mathrm{nM}), 5 \mu \mathrm{L} 10 \times$ PCR buffer $(100 \mathrm{mM}$ Tris-HCl, pH 8.3, $500 \mathrm{mM} \mathrm{KCl}, 15 \mathrm{mM}$ $\left.\mathrm{MgCl}_{2}\right), 38.75 \mu \mathrm{L}$ deionized water and $1 \mu \mathrm{L}$ each of the $5^{\prime}$ and $3^{\prime}$ oligonucleotide primers $\left(1 \mathrm{mg} \cdot \mathrm{mL}^{-1}\right)$ (Eurogentec, Sart Tilman, Belgium). The DNA was amplified in a threetemperature programmable thermocycler (Perkin-Elmer Cetus, Emeryville, CA, USA). SC-DNA oligonucleotide sequencing, denaturating, annealing and extension conditions were as described by FINKBEINER et al. [24]. Amplification products were separated by electrophoresis $(100 \mathrm{~V}$ constant-voltage field) on a $2 \%$ agarose gel (BioRad).

\section{Statistical methods}

Data are expressed as mean \pm SD. Statistical analysis of the data included an overall analysis of variance (ANOVA) followed by paired t-tests, using Statview (Abacus software for Macintosh). A probability value of $<0.05$ was considered significant.

\section{Results}

\section{SC production by respiratory epithelial cell lines}

No measurable SC level was found in the medium of A549 cells at 24, 48, 72 and $96 \mathrm{~h}$ after reaching confluence even after $10 \times$ concentration. However, detectable but very low levels of SC were found in 16HBE culture media after $10 \times$ concentration at $48 \mathrm{~h}$. The third cell line, CALU-3, was used as a positive control. Significant production of SC by CALU-3 cells was confirmed (table 1).

SC production by nonpolarized HBEC in primary cultures: IFN- $\gamma$ upregulation

No significant difference in SC production between control and IFN- $\gamma$ incubated HBEC was found after $24 \mathrm{~h}$ (3.6 \pm 4.5 versus $4.5 \pm 4.7 \mathrm{ng} \cdot \mathrm{mL}^{-1}$ per $10^{5}$ cells, nonsignificant (Ns)) (fig. 1). After $48 \mathrm{~h}$, however, there was a significant increase in SC production by IFN- $\gamma$ treated HBEC compared with control HBEC $(8.9 \pm 7.1$ versus $4.5 \pm 4.1$ $\mathrm{ng} \cdot \mathrm{mL}^{-1}$ per $10^{5}$ cells, $\left.\mathrm{p}<0.01\right)$. This increased SC production by IFN- $\gamma$ treated cells persisted after $72 \mathrm{~h}(13.0 \pm 6.8$ versus $5.7 \pm 3.7 \mathrm{ng} \cdot \mathrm{mL}^{-1}$ per $10^{5}$ cells, $\left.\mathrm{p}<0.01\right)$. No significant difference was found in SC production by control HBEC after 24, 48 and $72 \mathrm{~h}$ without IFN- $\gamma$.

Table 1. - Secretory component production by confluent nonpolarized A549, 16HBE and CALU-3 at 24, 48, 72 and $96 \mathrm{~h}$ and HBEC $(\mathrm{n}=10)$ at 24,48 and $72 \mathrm{~h}$

\begin{tabular}{lllll}
\hline Cells $/ 10^{5}$ & \multicolumn{4}{c}{ Time $\mathrm{h}$} \\
\cline { 2 - 5 } & \multicolumn{1}{c}{24} & \multicolumn{1}{c}{48} & \multicolumn{1}{c}{72} & \multicolumn{1}{c}{96} \\
\hline A549 $\mathrm{ng} \cdot \mathrm{mL}^{-1}$ & $<0.005$ & $<0.005$ & $<0.005$ & $<0.005$ \\
16HBE $\mathrm{ng} \cdot \mathrm{mL}^{-1}$ & $<0.01$ & 0.05 & $<0.01$ & $<0.01$ \\
CALU-3 $\mathrm{ng} \cdot \mathrm{mL}^{-1}$ & 12.4 & 12.4 & 10.9 & 12.4 \\
HBEC $\mathrm{ng} \cdot \mathrm{mL}^{-1}$ & $3.5 \pm 4.1$ & $4.2 \pm 4.0$ & $4.7 \pm 3.9$ & \\
\hline
\end{tabular}

HBEC: human bronchial epithelial cells. 


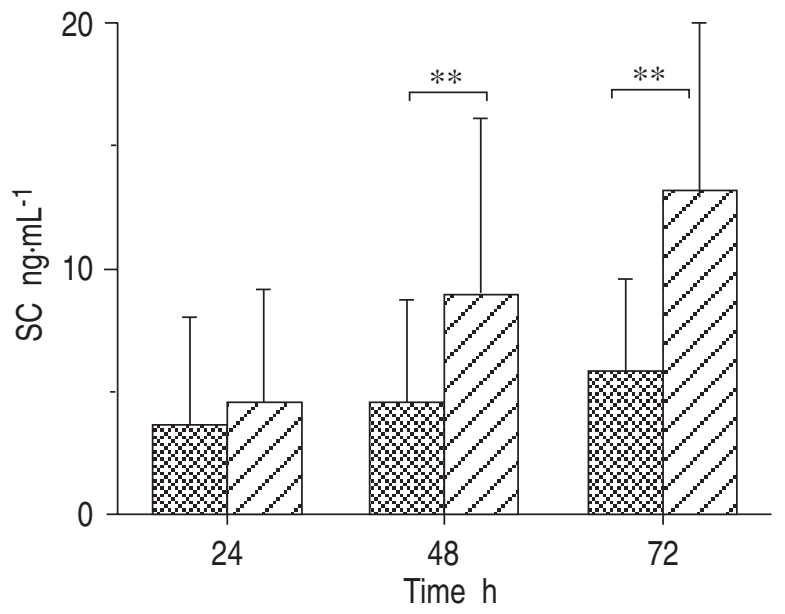

Fig. 1. - Secretory component (SC) production by human bronchial epithelial cells in nonpolarized primary culture, at 24,48 and $72 \mathrm{~h}$ after confluence, in the presence $(\nabla \Delta)$ or absence ( $\$ \otimes)$ of interferon$\gamma 100 \mathrm{U} \cdot \mathrm{mL}^{-1}(\mathrm{n}=8)$. Results are expressed in $\mathrm{ng} \mathrm{SC} \cdot \mathrm{mL}^{-1}$ per $10^{5}$ cells. $* *: \mathrm{p}<0.01$.

Apical SC production by polarized HBEC in primary cultures

At 24, 48 and $72 \mathrm{~h}$, SC concentrations were significantly higher in the media collected at the apical pole of the control and IFN- $\gamma$-treated cells than in the media from the basolateral compartment $(\mathrm{p}<0.01)$ (fig. 2).

After $24 \mathrm{~h}$, apical SC production by control HBEC was not significantly different from that by HBEC incubated with $100 \mathrm{U} \cdot \mathrm{mL}^{-1} \mathrm{IFN}-\gamma\left(2.4 \pm 1.0\right.$ versus $4.1 \pm 1.7 \mathrm{ng} \cdot \mathrm{mL}^{-1}$, Ns). After $48 \mathrm{~h}$, apical media collected from HBEC incubated with IFN- $\gamma$ contained higher concentrations of SC than apical media from control HBEC (12.7 \pm 5.4 versus $4.2 \pm 1.0 \mathrm{ng} \cdot \mathrm{mL}^{-1}$ per $10^{5}$ cells, $\left.\mathrm{p}<0.04\right)$. After $72 \mathrm{~h}$ apical media collected from IFN- $\gamma$ stimulated HBEC contained significantly higher concentrations of SC than did apical media from control HBEC $(11.1 \pm 2.3$ versus $3.2 \pm 0.3$

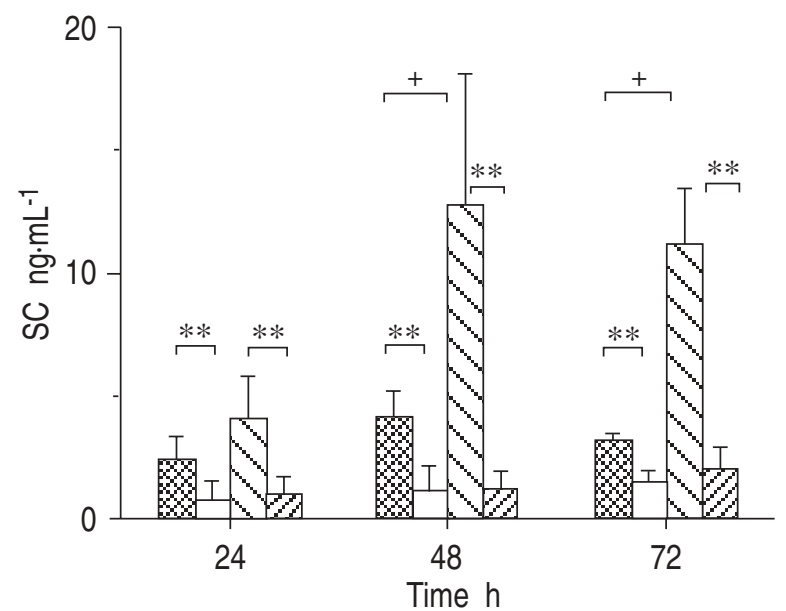

Fig. 2. - Secretory component (SC) production by human bronchial epithelial cells in polarized primary culture, at 24,48 and $72 \mathrm{~h}$ after confluence, in the presence or absence of interferon- $\gamma(\mathrm{IFN}-\gamma)\left(100 \mathrm{U} \cdot \mathrm{mL}^{-1}\right)$ in the apical media $(n=4)$. SC concentrations were measured in the apical and basolateral media. $\mathrm{X}$ : control apical; $\square$ : control basolateral; 1 IFN apical; $Z 2$ : IFN basolateral. In control and IFN- $\gamma$ conditions, SC concentrations were significantly higher in the apical than in the basolateral media $(\mathrm{p}<0.01)$. $+\mathrm{p}<0.04 ; * *$ : $\mathrm{p}<0.01$. ng. $\mathrm{mL}^{-1}$ per $10^{5}$ cells, $\mathrm{p}<0.02$ ). No significant difference was found in the low SC levels of the basolateral media from control and IFN- $\gamma$ treated cells (fig. 2).

In three distinct experiments, HBEC were first cultured on Petri dishes coated with coating solution, then detached by trypsinization and further cultured on $0.4 \mu \mathrm{m}$ coated

a)

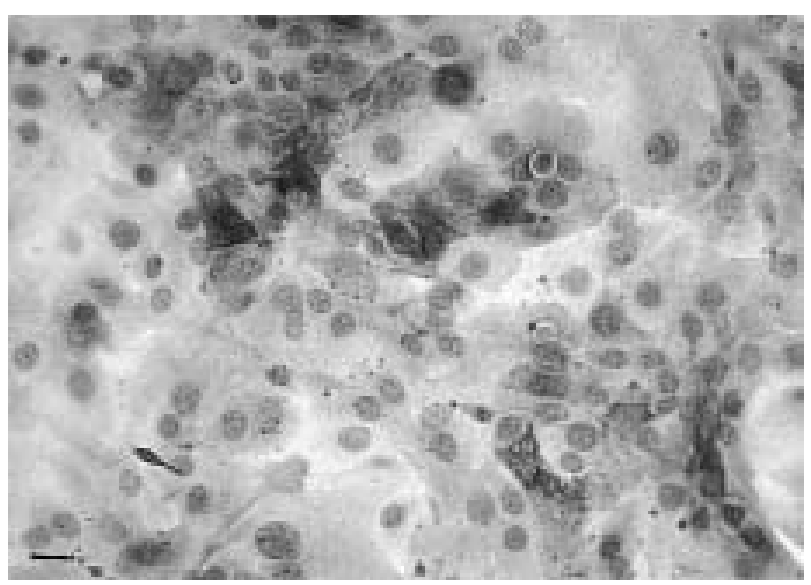

b)

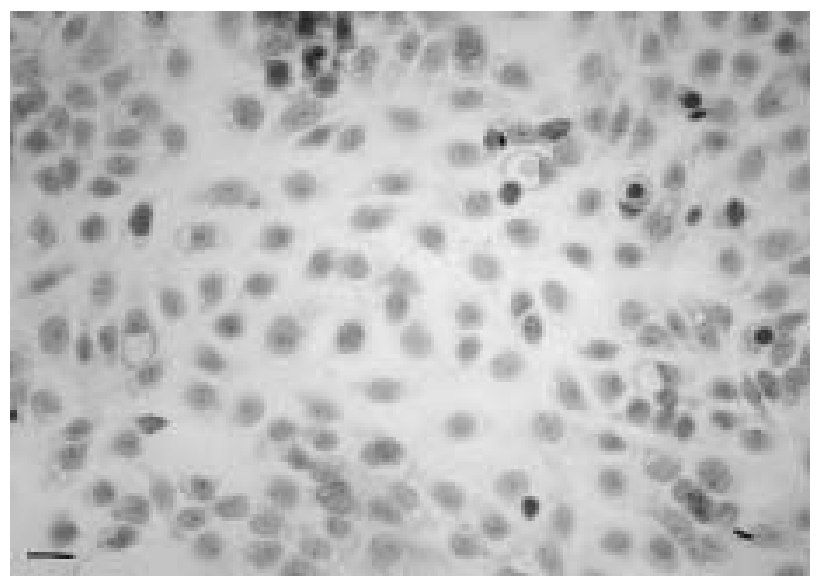

c)

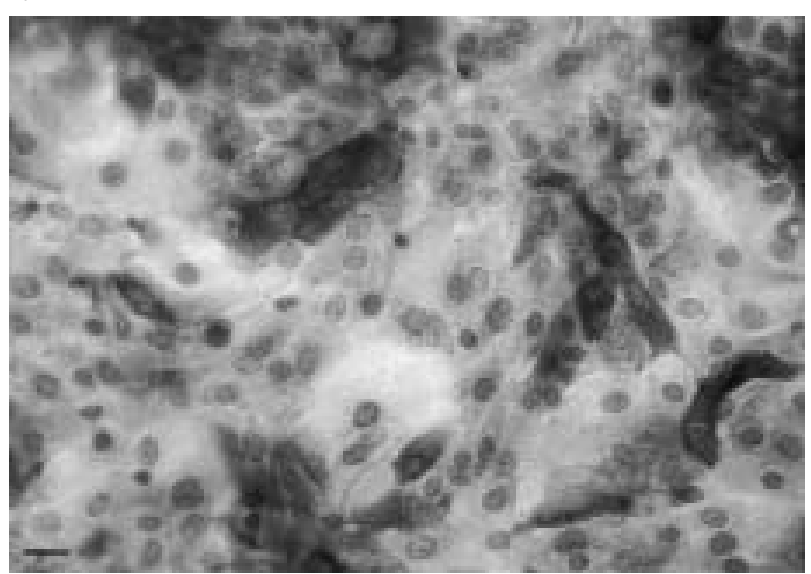

Fig. 3. - a) Confluent primary culture of human bronchial epithelial cells (HBEC) on a glass slide. Indirect immunoperoxidase secretory component (SC) staining in nonstimulated HBEC. b) Negative control for SC immunostaining using bovine serum albumin instead of antiSC as the primary antibody. c) Immunoperoxidase SC staining in HBEC incubated for $48 \mathrm{~h}$ with interferon- $\gamma\left(100 \mathrm{U} \cdot \mathrm{mL}^{-1}\right)$. (Internal scale bars= $25 \mu \mathrm{m})$. 
inserts. Confluence on the inserts was reached after a mean 6 days of culture. In these conditions after one passage, HBEC produced lower concentrations of SC in the insert media than when directly seeded on inserts (data not shown).

\section{Immunocytochemistry}

In five experiments, cultured HBEC were constitutively mildly to moderately immunostained for SC, although a few cells were not. Small groups of cells showed stronger SC immunostaining, suggesting higher SC production. Controls with BSA instead of anti-SC antibody showed no SC staining (fig. $3 a$ and $b$ ).

In three of these five experiments, after incubation with IFN- $\gamma\left(100 \mathrm{U} \cdot \mathrm{mL}^{-1}\right)$ for $48 \mathrm{~h}$, HBEC demonstrated an increased intensity of SC immunostaining, with an increased number of cells exhibiting high-intensity immunostaining (fig. 3c).

In three further experiments, the epithelial nature of the majority of the confluent HBEC was proven by their staining by anticytokeratin 8 and 18 monoclonal antibody. HBEC showed no staining when using the IgG2a isotype control antibody (fig. 4a and b).

a)

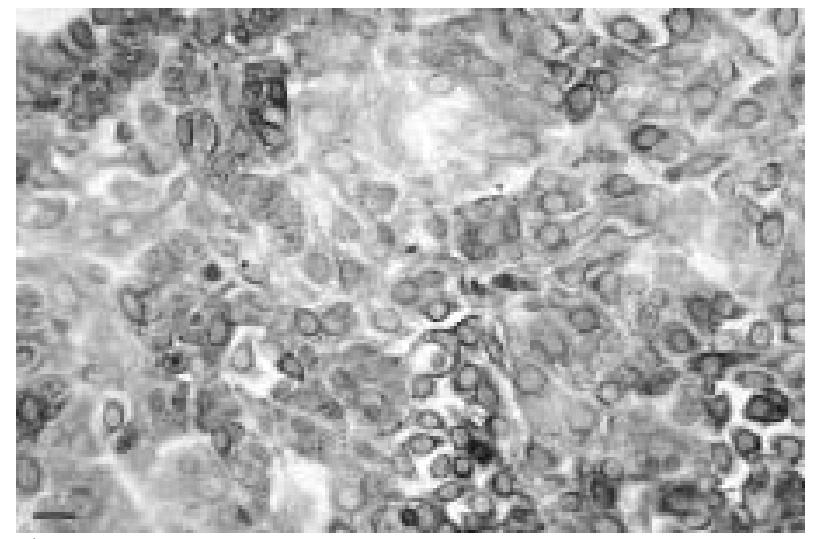

b)

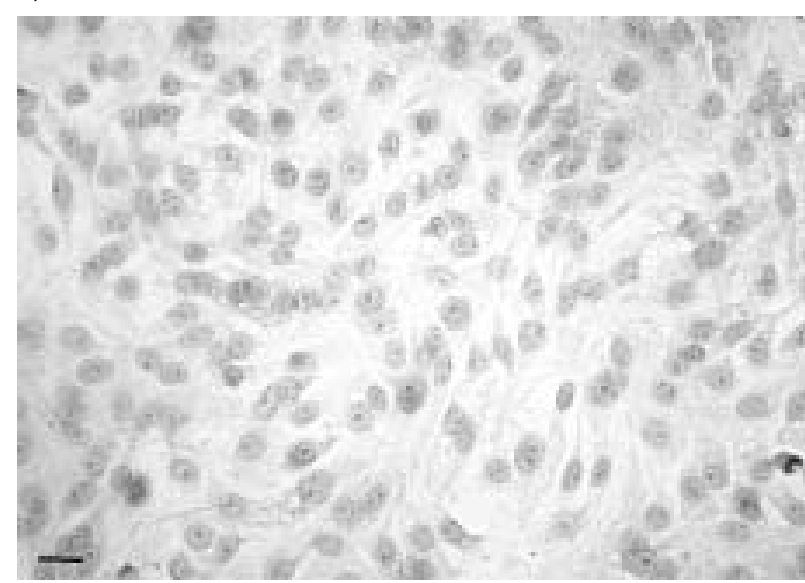

Fig. 4. - a) Confluent primary culture of human bronchial epithelia cells (HBEC) on glass slide stained with monoclonal anticytokeratin 8 and 18 antibody to confirm their epithelial nature. b) Negative control of cytokeratin immunostaining using an irrelevant immunoglobulin G2a monoclonal antibody as an isotype control. (Internal scale bars $=25 \mu \mathrm{m}$ ).

\section{Transcytosis of cold and ${ }^{125}$ I-labelled dIgA}

In five separate experiments, significant ${ }^{125} \mathrm{I}-\mathrm{dIg} \mathrm{A}$ concentrations were found in the apical medium of experimental wells at $24 \mathrm{~h}\left(2.5 \pm 1.0 \mathrm{ng} \cdot \mathrm{mL}^{-1}{ }^{125} \mathrm{I}-\mathrm{d} \operatorname{IgA}\right)$. The ${ }^{125} \mathrm{I}-\mathrm{dIgA}$ concentration increased over time at $48 \mathrm{~h}\left(4.2 \pm 1.5 \mathrm{ng} \cdot \mathrm{mL}^{-1}\right.$ $\left.{ }^{125} \mathrm{I}-\mathrm{dIgA}, \mathrm{p}<0.03\right)$ and at $72 \mathrm{~h}\left(8.4 \pm 2.0 \mathrm{ng} \cdot \mathrm{mL}^{-1} 125 \mathrm{I}-\mathrm{dIgA}\right.$, $\mathrm{p}<0.03)$. $125 \mathrm{I}$-dIgA concentrations in apical medium of control wells with cold $\mathrm{pIgA}$ in excess were significantly lower $\left(0.2 \pm 0.1 \mathrm{ng} \cdot \mathrm{mL}^{-1}{ }^{125} \mathrm{I}-\mathrm{dIgA}\right.$ at $24 \mathrm{~h}, 0.8 \pm 0.4 \mathrm{ng} \cdot \mathrm{mL}^{-1}{ }^{125} \mathrm{I}-$ $\mathrm{dIgA}$ at $48 \mathrm{~h}$ and $1.2 \pm 0.4 \mathrm{ng} \cdot \mathrm{mL}^{-1}{ }^{125} \mathrm{I}-\mathrm{dIgA}$ at $72 \mathrm{~h}$, $\mathrm{p}<0.05$ ) (fig. 5a).

In four of these five experiments, ${ }^{125 I-d I g A}$ transcytosis was compared by HBEC incubated with and without (control) IFN- $\gamma 100 \mathrm{U} \cdot \mathrm{mL}^{-1}$. At $48 \mathrm{~h}, \mathrm{HBEC}$ incubated with IFN- $\gamma$ transported higher concentrations of $125 \mathrm{I}-\mathrm{dIgA}$ in their apical medium than HBEC without IFN- $\gamma(7.54 \pm 2.4$
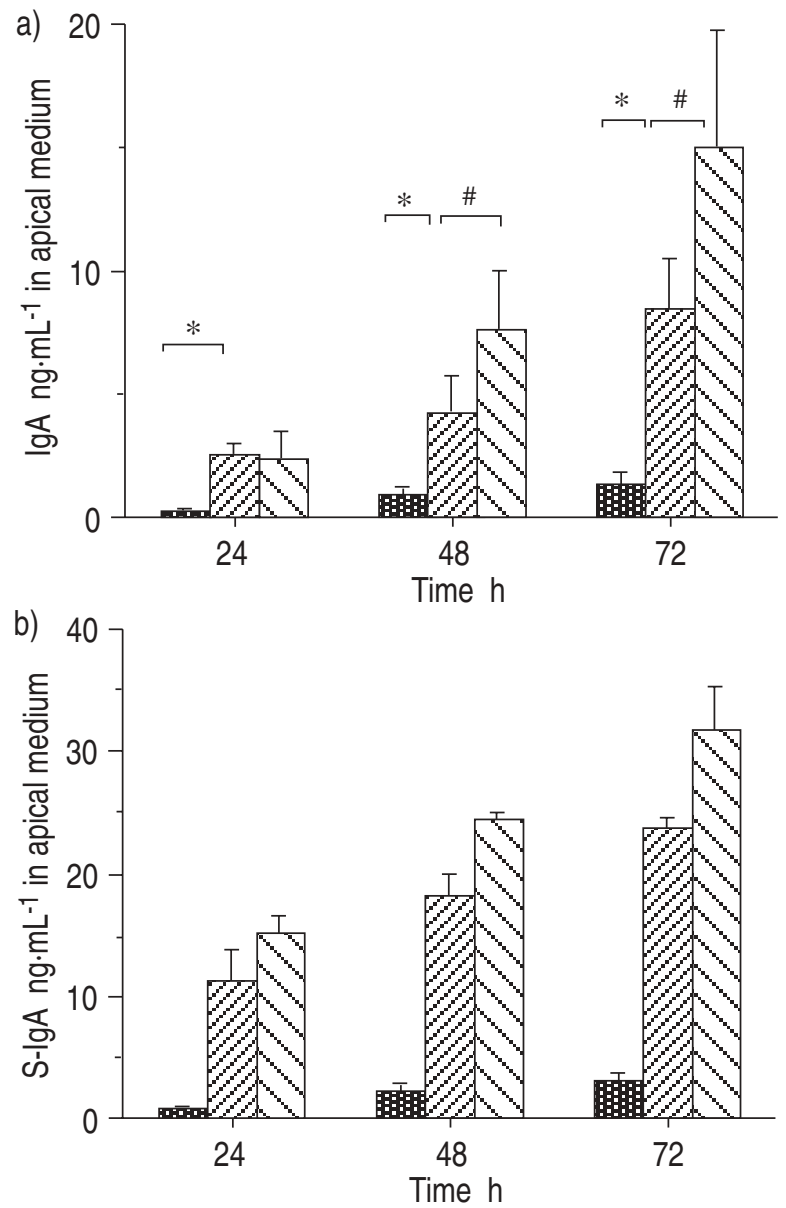

Fig. 5. - a) Transcytosis of 125 I-dimeric immunoglobulin A (dIgA) by polarized confluent human bronchial epithelial cells (HBEC) at 24, 48 and $72 \mathrm{~h}$ after confluence. ${ }^{125 I-d I g A}$ at $8 \mu \mathrm{g} \cdot \mathrm{mL}^{-1}$ was added in the basolateral media, in the presence ( $Q 2$ ) or absence (W) of interferon- $\gamma$ (IFN- $\gamma)\left(100 \mathrm{U} \cdot \mathrm{mL}^{-1}\right)$ in the apical media. control included the addition of $4.2 \mathrm{mg} \cdot \mathrm{mL}^{-1}$ cold polymeric IgA to the same concentration of ${ }^{125 I-d I g A}(n=5)$. Results are expressed as trichloroacetic acid-precipitable ${ }^{125} \mathrm{I}-\mathrm{dIgA}$ in $\mathrm{ng} \cdot \mathrm{mL}^{-1}$. \#: $\mathrm{p}<0.03$; *: $\mathrm{p}<0.05$. b) Transcytosis of cold $\mathrm{dIgA}\left(2 \mathrm{mg} \cdot \mathrm{mL}^{-1}\right)$ by polarized confluent HBEC at 24,48 and $72 \mathrm{~h}$ in the presence ( $Z 2)$ or absence ( $\left.\mathrm{U} \cdot \mathrm{mL}^{-1}\right)$ in the apical media. Secretory $(\mathrm{S})$ - IgA concentrations are measured in the apical media and expressed in ng. $\mathrm{mL}^{-1}$; no S-IgA could be found in the basolateral media. Negative control conditions consisted of the same concentration of cold monomeric IgA. Two experiments were conducted. 
$\mathrm{ng} \cdot \mathrm{mL}^{-1}{ }^{125} \mathrm{I}-\mathrm{dIgA}$ with IFN- $\gamma$ versus $4.2 \pm 1.5 \mathrm{ng} \cdot \mathrm{mL}^{-1}{ }^{125} \mathrm{I}-$ dIgA without, $\mathrm{p}<0.03$ ). This IFN- $\gamma$ enhancing effect on dIgA transcytosis by HBEC significantly persisted at $72 \mathrm{~h}$ $\left(15.0 \pm 4.7 \mathrm{ng} \cdot \mathrm{mL}^{-1}{ }^{125} \mathrm{I}-\mathrm{dIgA}\right.$ versus $8.4 \pm 2.0 \mathrm{ng} \cdot \mathrm{mL}^{-1}{ }^{125} \mathrm{I}-$ dIgA at 72 h, p<0.02) (fig. 5a).

In two experiments, confluent HBEC monolayers were incubated for 24,48 and $72 \mathrm{~h}$ with cold $\operatorname{dIgA}\left(2 \mathrm{mg} \cdot \mathrm{mL}^{-1}\right)$ in the basolateral media. Control HBEC included in these two experiments were incubated with cold monomeric $\operatorname{IgA}(\mathrm{mIg} \mathrm{A})$ at the same concentration in the basolateral medium. Increasing concentrations of $\mathrm{S}$-IgA were found in the apical media of HBEC after 24, 48 and $72 \mathrm{~h}$ where dIgA was present in the basolateral media $(11.1 \pm 2.5$, $18.1 \pm 1.9$ and $23.6 \pm 0.8 \mathrm{ng} \cdot \mathrm{mL}^{-1}$, respectively). Apical media of control HBEC incubated with mIgA in their basolateral media only contained much lower concentrations of $\mathrm{S}$ $\operatorname{IgA}\left(0.8 \pm 0.03,2.3 \pm 0.7\right.$, and $\left.2.8 \pm 0.7 \mathrm{ng} \cdot \mathrm{mL}^{-1}\right)$. No measurable S-IgA was found in the basolateral media with our assay in either control or experimental conditions. When HBEC were incubated with $\operatorname{dIgA}$ in the basolateral medium and with IFN- $\gamma\left(100 \mathrm{U} \cdot \mathrm{mL}^{-1}\right)$ in the apical med-

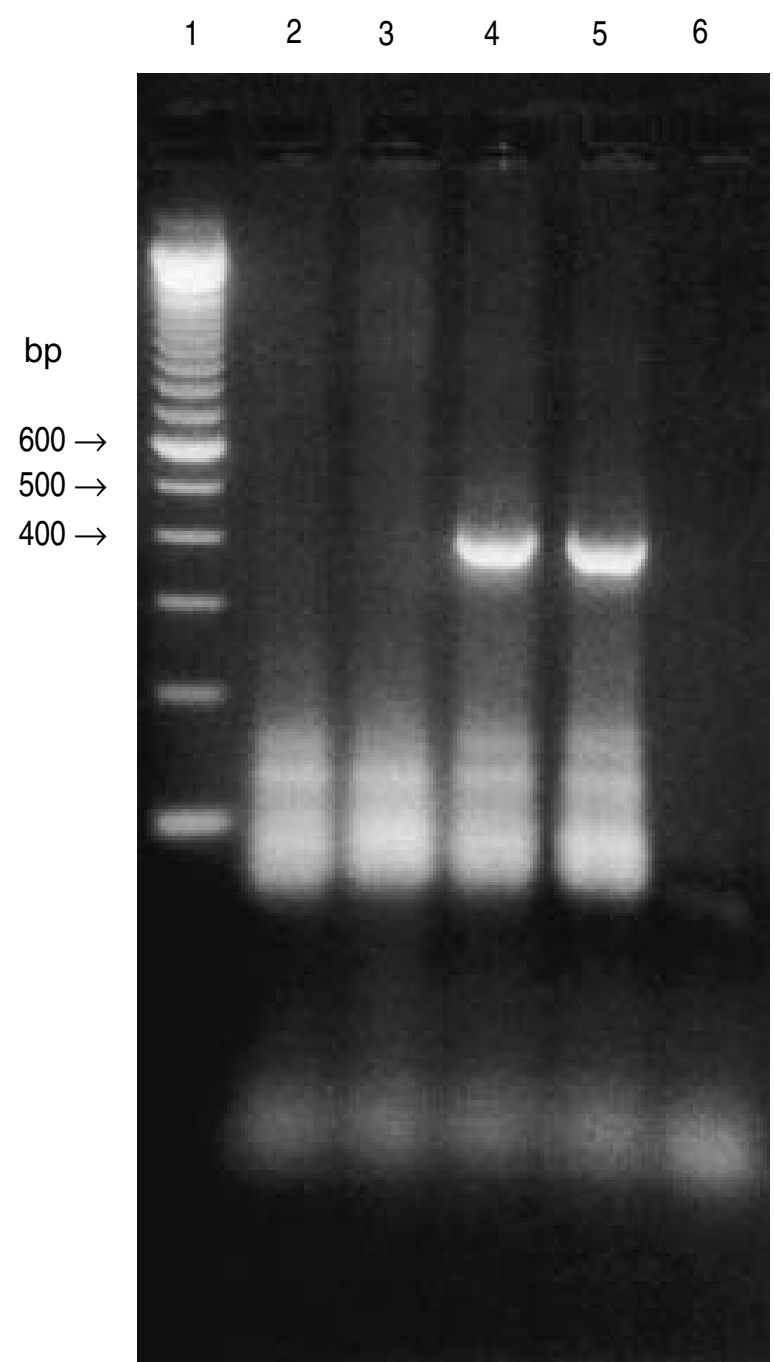

Fig. 6. - Ethidium bromide-stained polyacrylamide gel of reverse transcription-polymerase chain reaction products from cell lines A549 (lane 2 ), 16HBE (lane 3) and interferon- $\gamma$-stimulated human bronchoepithelial cells (lane 5), with CALU-3 (lane 4) as a positive control and human bone marrow cells as a negative control (lane 6). bp: base pair. ium, the concentrations of $\mathrm{S}-\operatorname{IgA}$ in the apical media were higher after 24,48 and $72 \mathrm{~h}(15.2 \pm 1.4 ; 24.4 \pm 0.5,31.7 \pm 3.3$ $\mathrm{ng} \cdot \mathrm{mL}^{-1}$, respectively) than without IFN- $\gamma$. As these results originate from only two experiments they are not statistically evaluable (fig. 5b). Two additional experiments were carried out to assess HBEC permeability with and without IFN- $\gamma$. mIgA, a molecule that is not transcytosed by epithelial cells [20] was added at $100 \mu \mathrm{g} \cdot \mathrm{mL}^{-1}$ to the basolateral medium of confluent monolayers of HBEC and the mIgA concentration was measured in the apical media. No difference in HBEC permeability to mIgA was observed in control and IFN- $\gamma$ wells at 24 and $48 \mathrm{~h}$ $\left(8.3 \pm 0.4\right.$ versus $<8 \mathrm{ng} \cdot \mathrm{mL}^{-1} \mathrm{mIgA}$ at $24 \mathrm{~h}$ and $10.3 \pm 3.3$ versus $8.7 \pm 0.9 \mathrm{ng} \cdot \mathrm{mL}^{-1} \mathrm{mIgA}$ at $48 \mathrm{~h}$ ).

\section{$R T-P C R$}

The RT-PCR results for the presence of SC mRNA in HBEC and respiratory epithelial cell lines are shown in fig. 6. The negative control (lane 6) is represented by human bone marrow cells with the positive control (lane 4) being CALU-3. The two other cell lines, A549 and $16 \mathrm{HBE}$ (lanes 2 and 3, respectively), expressed no detectable SC mRNA. HBEC incubated for $48 \mathrm{~h}$ with IFN- $\gamma$ (lane 5) expressed SC mRNA at a level comparable to that of CALU-3, at 405 base pairs.

\section{Discussion}

The secretory immune system plays a major role in protecting the respiratory tract from viral and bacterial infections. $\mathrm{S}-\operatorname{Ig} \mathrm{A}$ is the major immunoglobulin present in the respiratory secretions in humans and at the bronchial level is mainly involved in the immune exclusion process, a noninflammatory pathway [3]. The mechanisms of SC production and pIgA transcytosis by bronchial epithelial cells and their regulation remain underinvestigated. In order to study these mechanisms an in vitro model of SC production and IgA transcytosis by bronchial epithelial cells was used.

Studies at the protein level demonstrate SC production by HBEC and CALU-3 in nonpolarized cultures, no SC production by $\mathrm{A} 549$ and a minimal production of SC by 16HBE. When cultured on filter inserts, HBEC secretion of SC was apically polarized. Moreover, polarized HBEC were capable of transcytosing dIgA, released as S-IgA in the apical compartment of the cell culture system, while no S-IgA was detected in the basolateral compartment (results from two experiments). The addition of $100 \mathrm{U} \cdot \mathrm{mL}^{-1}$ IFN- $\gamma$ gave a steady and reproducible increase in SC production and $\mathrm{dIgA}$ transcytosis after 48 and $72 \mathrm{~h}$. Immunocytochemical studies showed that SC production was heterogeneously distributed in HBEC. IFN- $\gamma$ increased the proportion of SC-positive cells and the amount of SC produced by SC-positive cells. At the molecular level, RT-PCR showed that A549 and 16HBE cells did not express detectable mRNA for SC, while HBEC with IFN- $\gamma$ expressed SC mRNA at the same level as CALU-3 cells used as a positive control [24].

SC production and transcytosis of immunoglobulins are major properties of epithelial cells, allowing the unidirectional transport of polymeric antibodies, without disturbing the integrity of the epithelial barrier. FIEDLER et al. [10] 
demonstrated that primary human tracheal epithelial cells [10] produced SC in vitro. Transcytosis has already been suggested in the human bronchial epithelium by in situ immunoelectron microscopy [7]. The mechanisms of pIgA transcytosis have been investigated in vitro mainly in polarized Madin-Darby canine kidney (MDCK) cells stably transfected with the cDNA encoding the rabbit pIgR $[20,25]$. However, because of the viral vector of transfection, these systems do not allow the study of the influence of cytokines on pIgA transcytosis. A recent study using an animal model demonstrated pIgA transcytosis in polarized primary cultures of rat uterine epithelial cells [26]. Another group has studied pIgA transcytosis by CALU-3, a bronchial epithelial cell line with characteristics of serous glands [27]. To the best of our knowledge, pIgA transcytosis had not previously been studied in primary HBEC cultures.

Previous studies have stressed the influence of epithelial cell polarization on SC secretion $[10,11]$. CHINTALACHARUvU et al. [11] extensively demonstrated that depolarization, induced by calcium deprivation, significantly decreased the total release of SC by HT-29.74 human colon carcinoma cells. Like FIEDLER et al. [10] we found that SC release by HBEC in primary culture on permeable filters was apically polarized. In our studies, apical SC secretion and pIgA transcytosis by HBEC were dependent on cell polarization, since SC was released mainly in the apical medium in polarized cultures.

Studies of cytokine modulation of SC production and pIgA transcytosis by HBEC are crucial to understand the regulation of these mechanisms in vivo. From previous studies, IFN- $\gamma$ appeared consistently to stimulate SC production by human intestinal epithelial cell lines [12, 13]. Therefore the effect of IFN- $\gamma$ on SC production by HBEC was studied. HBEC increased their SC production after 48 $h$ incubation with IFN- $\gamma$ in nonpolarized and in polarized cultures. In polarized cultures, this increased SC production was largely apically released. However, IFN- $\gamma$ has been found to increase the permeability and decrease the transepithelial electrical resistance of a human colonic epithelial cell-line (T84) monolayer [28] when added basolaterally. No increased permeability was found when IFN$\gamma$ was added to the apical medium. We have confirmed that apically added IFN- $\gamma$ did not alter the permeability of the HBEC monolayer. Other cytokines such as IL- $1 \alpha$ and $\beta$, IL-4, TNF- $\alpha$ and TGF- $\beta$ [12-17] have been shown to up-regulate the production of SC by intestinal cell lines, but have not been studied here.

At the transcriptional level, the results using the RTPCR technique confirmed the expression of RNA for SC by the CALU-3 cells [24]. Furthermore, SC mRNA was detected in primary HBEC, while A549 and 16HBE cells did not express detectable mRNA for SC, supporting the respective presence or virtual absence of SC production in culture. Previous studies have demonstrated the upregulation of mRNA for SC by IFN- $\gamma$ in cell line models [29, 30].

The immunocytochemistry data show that immunostaining for SC was not homogeneous in unpolarized HBEC. Such differences in SC immunostaining suggest heterogeneity in cellular content and/or heterogeneous production of SC by HBEC, possibly related to their original in vivo location in the bronchial pseudostratified epithelium, since several studies $[6,10,24]$ suggest that basal cells do not express SC. SC immunostaining of HBEC was increased after $48 \mathrm{~h}$ incubation with IFN- $\gamma$, suggesting that this cytokine increased the amount of SC produced per cell but also increased the total number of cells producing SC. It would be of interest to study SC immunostaining of polarized HBEC on inserts.

Viral and bacterial infections in the respiratory tract lead to the release of various cytokines, including IFN- $\gamma$, by macrophages, lymphocytes and epithelial cells [31, 32]. This release of IFN- $\gamma$ is likely to upregulate the secretion of SC and the transcytosis of immunoglobulins by the bronchial epithelium, increasing the efficacy of the immune exclusion process. The recent finding of a strong interaction between a common pneumococcal surface protein (SpsA) and both S-IgA and SC strengthens the relevance of these data [33]. Mucosal immunity mechanisms remain poorly explored in respiratory diseases. Our group found diminished concentrations of SC in the BAL of asthmatics compared with normal controls [8], which could be related to the imbalance between Th1 and Th2 subpopulations of T-lymphocytes in asthmatics [34, 35], resulting in the downregulation of IFN- $\gamma$ release.

HBEC used in these studies were obtained from "healthy" segments of bronchi removed from the lungs of patients who had undergone lobectomy for lung cancer. Although no major inflammatory or metaplasic changes were observed in the samples used, these bronchi were obtained from patients with a history of smoking and mild chronic obstructive pulmonary disease (COPD). Inflammatory changes typical in COPD are possibly accompanied by functional changes in protein secretion and production by epithelial cells, as it has been shown to be the case in asthmatic epithelial cells [36] or in Clara cell protein (CC10) production by epithelial cells from smokers [37]. It is therefore possible that the present kinetics of SC production differ somewhat from those of HBEC from normal nonsmoking subjects. Differences between donors are also possible because of differences in age, gender and medical history. The technique of cell separation by enzymatic dissociation at low temperatures induces loss of differentiation of the retrieved epithelial cells [38-40]; however, the risk of fibroblast contamination is very low, which is important because epithelial SC production can be inhibited by fibroblasts [41]. HBEC obtained by outgrowth from normal explants would have been a good alternative. However, this type of culture is characterized by the presence of squamous epithelial cells, which usually do not produce SC, at the outgrowth edges. Other limitations include the small number of experiments for each condition investigated and the number of epithelial cells recovered from surgery specimen according to their size.

In summary, these studies have demonstrated a constitutive secretory component production by human bronchial epithelial cells enhanced by cell polarization and by interferon gamma. Secretory component messenger ribonucleic acid were detected in human bronchial epithelial cells by reverse transcription-polymerase chain reaction. Among the cell-lines investigated however, A549 and $16 \mathrm{HBE}$ cells did not express messenger ribonucleic acid for polymeric immunoglobulin receptor. Furthermore, we were able to reproduce dimeric immunoglobulin A transcytosis by human bronchial epithelial cells in vitro and to underline its upregulation by interferon gamma. 
Acknowledgements: The authors wish to thank J.C. Schoevaerdts and B. Wynand for providing them with the surgery specimens and E. Puchelle for her help with the primary cultures.

\section{References}

1. Underdown BJ, Mestecky J. Mucosal immunoglobulins. In: Ogra PL, Mestecky J, Lamm ME, Strober W, McGhee JR, Bienenstock J, eds. Handbook of Mucosal Immunology. San Diego, Academic Press 1994: pp. 79-97.

2. Mostov KE, Kraehenbuhl JP, Blobel G. Receptor-mediated transcellular transport of immunoglobulin: synthesis of secretory component as multiple and larger transmembrane forms. Proc Natl Acad Sci USA 1980; 77: 72577261.

3. Brandtzaeg P. The role of humoral mucosal immunity in the induction and maintenance of chronic airway infections. Am J Respir Crit Care Med 1995; 151: 2081-2087.

4. Mostov KE, Cardone MH. Regulation of protein traffic in polarized epithelial cells. Bioessays 1995; 17: 129-138.

5. Mazanec MB, Nedrud JG, Kaetzel CS, Lamm ME. A three-tiered view of the role of $\operatorname{IgA}$ in mucosal defense. Immunol Today 1993; 14: 429-434.

6. Takemura T, Eishi Y. Distribution of secretory component and immunoglobulins in the developing lung. Am Rev Respir Dis 1985; 131: 125-130.

7. Goodman MR, Link D, Brown WR, Nakane PK. Ultrastructural evidence of transport of secretory $\operatorname{IgA}$ across bronchial epithelium. Am Rev Respir Dis 1981; 123: 115119.

8. Van Vyve T, Chanez P, Bernard A, et al. Protein content in bronchoalveolar lavage fluid of patients with asthma and control subjects. J Allergy Clin Immunol 1995; 95: 60-68.

9. Gleeson M, Clancy RL, Hensley MJ, et al. Development of bronchial hyperreactivity following transient absence of salivary IgA. Am J Respir Crit Care Med 1996; 153: 1785-1789.

10. Fiedler MA, Kaetzel CS, Davis P. Sustained production of secretory component by human tracheal epithelial cells in primary culture. Am J Physiol 1991; 261: L255-L261.

11. Chintalacharuvu KR, Piskurich JF, Lamm ME, Kaetzel CS. Cell polarity regulates the release of secretory component, the epithelial receptor for polymeric immunoglobulins, from the surface of HT-29 colon carcinoma cells. $J$ Cell Physiol 1991; 148: 35-47.

12. Piskurich JF, France JA, Tamer CM, Willmer CA, Kaetzel CS, Kaetzel DM. Interferon- $\gamma$ induces polymeric immunoglobulin receptor mRNA in human intestinal epithelial cells by a protein synthesis dependent mechanism. Mol Immunol 1993; 30: 413-421.

13. Phillips JO, Everson MP, Moldoveanu Z, Lue C, Mestecky J. Synergistic effect of IL-4 and IFN- $\gamma$ on the expression of polymeric Ig receptor (secretory component) and IgA binding by human epithelial cells. J Immunol 1990; 145: 1740-1744.

14. Denning GM. IL-4 and IFN- $\gamma$ synergistically increase total polymeric IgA receptor level in human intestinal epithelial cells. Role of protein tyrosine kinases. J Immunol 1996; 156: 4807-4814.

15. Kvale D, Lofhaug D, Sollid L, Brandtzaeg P. Tumor necrosis factor $\alpha$ upregulates expression of secretory component, the epithelial receptor for polymeric Ig. $J$ Immunol 1988; 140: 3086-3089.

16. McGee DW, Aicher WK, Eldridge JH, Peppard JV,
Mestecky J, McGhee JR. Transforming growth factor- $\beta$ enhances secretory component and major histocompatibility complex class I antigen expression in rat IEC-6 intestinal epithelial cells. Cytokine 1991; 3: 543-550.

17. Hayashi M, Takenouchi N, Asano M, et al. The polymeric immunoglobulin receptor (secretory component) in a human epithelial cell-line is upregulated by interleukin1. Immunology 1997; 92: 220-225.

18. Delacroix DL, Vaerman JP. Reassessment of levels of secretory $\operatorname{IgA}$ in pathological sera using a quantitative radioimmunoassay. Clin Exp Immunol 1981; 43: 633640.

19. Katona IM, Urban JF, Scher I, Kanellopoulos-Langevin C, Finkelman D. Induction of an IgE response in mice by Nippostrongylus brasiliensis: characterization of lymphoid cells with intracytoplasmic or surface IgE. J Immunol 1983; 130: 350-356.

20. Song W, Vaerman JP, Mostov KE. Dimeric and tetrameric IgA are transcytosed equally by the polymeric Ig receptor. J Immunol 1995; 155: 715-721.

21. Acosta Altamirano G, Barranco-Acosta C, Van Roost E, Vaerman JP. Isolation and characterization of secretory $\operatorname{Ig} \mathrm{A}(\operatorname{sIg} \mathrm{A})$ and free secretory component (FSC) from rat bile. Mol Immunol 1980; 17: 1525-1537.

22. Chopra DP, Sullivan JK, Wille JJ, Siddiqui KM. Propagation of differentiating normal human tracheobronchial epithelial cells in serum-free medium. J Cell Physiol 1987; 130: 173-181.

23. Herard AL, Zahm JM, Pierrot D, Hinnrasky J, Fuchey C, Puchelle E. Epithelial barrier integrity during in vitro wound repair of the airway epithelium. Am J Respir Cell Mol Biol 1996; 15: 624-632.

24. Finkbeiner WE, Carrier SD, Teresi CE. Reverse transcription-polymerase chain reaction (RT-PCR) phenotypic analysis of cell cultures of human tracheal epithelium, tracheobronchial glands, and lung carcinomas. Am J Res-pir Cell Mol Biol 1993; 9: 547-556.

25. Mostov KE, Deitcher DL. Polymeric immunoglobulin receptor expressed in MDCK cells transcytoses IgA. Cell 1986; 46: 613-621

26. Richardson JM, Kaushic C, Wira CR. Polymeric immunoglobulin (Ig) receptor production and IgA transcytosis in polarized primary cultures of mature rat uterine epithelial cells. Biol Reprod 1995; 53: 488-498.

27. Loman S, Radl J, Jansen HM, Out TA, Lutter R. Vectorial transcytosis of dimeric IgA by the Calu- 3 human lung epithelial cell line: upregulation by IFN-gamma. Am J Physiol 1997; 275: L951-L958

28. Adams RB, Planchon SM, Roche JK. IFN- $\gamma$ modulation of epithelial barrier function. Time course, reversibility and site of cytokine binding. J Immunol 1993; 150: 23562363.

29. Krajci P, Tasken K, Kvale D, Brandtzaeg P. Interferongamma stimulation of messenger RNA for human secretory component (poly-Ig receptor) depends on continuous intermediate protein synthesis. Scand J Immunol 1993; 37: 351-356.

30. Krajci P, Solberg R, Sandberg M, Oyen O, Jahnsen T, Brandtzaeg P. Molecular cloning of the human transmembrane secretory component (poly-Ig-receptor) and its mRNA expression in human tissues. Biochem Biophys Res Comm 1989; 158: 783-789.

31. Johnston SL. Natural and experimental rhinovirus infections of the lower respiratory tract. Am J Respir Crit Care Med 1995; 152: S46-S52.

32. Fraenkel DJ, Bardin PG, Sanderson G, Lampe F, Johnston SL, Holgate ST. Lower airways inflammation during 
rhinovirus colds in normal and asthmatic subjects. Am $J$ Respir Crit Care Med 1995; 151: 879-886.

33. Hammerschmidt S, Talay SR, Brantzaeg P, Chhatwal GS. SpsA, a novel pneumococcal surface protein with specific binding to secretory immunoglobulin A and secretory component. Mol Microbiol 1997; 25: 1113-1124.

34. Romagnani S. Induction of Th1 and Th2 responses: a key role for the 'natural' immune response? Immunol Today 1992; 13: 379-381.

35. Robinson DS, Amid Q, King S. Predominant Th2 like bronchoalveolar T-lymphocyte population in atopic asthma. N Engl J Med 1992; 326: 298-304.

36. Victoria E, Marine M, Fossil A, De Franchise R, Motile $\mathrm{S}$. Increased expression of endothelin in bronchial epithelial cells of asthmatics and effect of corticosteroids. Am Rev Respir Dis 1992; 146: 1320-1325.

37. Shijubo N, Itoh Y, Yamaguchi T, et al. Serum and BAL Clara cell $10 \mathrm{kDa}$ protein (CC10) levels and CC10-posi- tive bronchiolar cells are decreased in smokers. Eur Respir J 1997; 10: 1108-1114.

38. Devalia JL, Sapsford RJ, Wells CW, Richman P, Davies RJ. Culture and comparison of human bronchial and nasal epithelial cells in vitro. Respir Med 1990; 84: 303312.

39. Jorissen M, Van der Schueren B, Van den Berghe H, Cassiman JJ. Contribution of in vitro culture methods for respiratory epithelial cells to the study of the physiology of the respiratory tract. Eur Respir J 1991; 4: 210-217.

40. Widdicombe JH, Coleman DL, Finkbeiner WE, Tuet IK. Electrical properties of monolayers cultured from cells of human tracheal mucosa. J Appl Physiol 1985; 58: 17291735.

41. Richardson JM, Wira CR. Uterine stromal cell suppression of pIgR production by uterine epithelial cells in vitro: a mechanism for regulation of pIgR production. $J$ Reprod Immunol 1997; 33: 95-112. 